\title{
Ecomorphometric structure of Restinga da Marambaia lizard community, Rio de Janeiro, southeastern Brazil
}

\author{
André L. G. de Carvalho ${ }^{1} \&$ Alexandre F. B. de Araújo ${ }^{2}$ \\ 1 Departamento de Vertebrados, Museu Nacional, Universidade Federal do Rio de Janeiro. Quinta da Boa Vista, São \\ Cristóvão, 20940-040 Rio de Janeiro, Rio de Janeiro, Brasil. E-mail: andreluizherpeto@gmail.com \\ ${ }^{2}$ Laboratório de Herpetologia, Departamento de Biologia Animal, Instituto de Biologia, Universidade Federal Rural do Rio de \\ Janeiro. Caixa Postal 74524, 23851-970 Seropédica, Rio de Janeiro, Brasil. E-mail: araujo@ufrri.br
}

\begin{abstract}
In restinga areas of Marambaia, Rio de Janeiro, we recorded nine species of lizards, grouped in four families. The morphometric analysis suggested an invasion-structured pattern, with two distinct groups of species in the community: the "ground-runners", composed of animals with robust bodies and long limbs, represented by Tropidurus torquatus (Wied, 1820), Ameiva ameiva (Linnaeus, 1758), Liolaemus lutzae Mertens, 1938, Cnemidophorus littoralis Rocha, Araujo, Vrcibradic \& Costa, 2000 and Tupinambis merianae (Duméril \& Bibron, 1839); and the “hiders", composed of small-bodied animals with short limbs, represented by Hemidactylus mabouia (Moreau de Jonnès, 1818), Gymnodactylus darwinii (Gray, 1845), Mabuya agilis (Raddi, 1823) and M. macrorhyncha Hoge, 1947. The morphological relationships within the restinga lizard community reflect the influence of the habitat physical structure: bromeliad availability and other refugia, used by the "hiders", and the distribution of open areas, used by the "ground-runners". Our results also indicate that the restingas hold "ecomorphological spaces" (vacant niches) available for occupation by additional lizard species.
\end{abstract}

KEY WORDS. Atlantic Forest; community structure; morphometry; vacant niche.

RESUMO. Estrutura ecomorfométrica da comunidade de lagartos da Restinga da Marambaia, Rio de Janeiro, sudeste do Brasil. Em áreas de restinga da Marambaia, Rio de Janeiro, foram registradas nove espécies de lagartos, pertencentes a quatro famílias. A análise morfométrica sugeriu um padrão de estruturação por invasão, com dois grupos distintos de espécies compondo a comunidade: os "corredores de chão", formado pelos animais de corpo mais robusto e membros mais longos, representados por Tropidurus torquatus (Wied, 1820), Ameiva ameiva (Linnaeus, 1758), Liolaemus lutzae Mertens, 1938, Cnemidophorus littoralis Rocha, Araujo, Vrcibradic \& Costa, 2000 e Tupinambis merianae (Duméril \& Bibron, 1839); e os "escondedores", reunindo lagartos de menor tamanho e membros mais curtos, representados por Hemidactylus mabouia (Moreau de Jonnès, 1818), Gymnodactylus darwinii (Gray, 1845), Mabuya agilis (Raddi, 1823) e M. macrorhyncha Hoge, 1947. As relações morfométricas dentro da comunidade de lagartos de restinga da Marambaia espelham a influência da estrutura física do habitat (habitat estrutural): a disponibilidade de bromélias e de outros locais para esconder, importantes para os lagartos "escondedores", assim como a distribuição de áreas abertas para os "corredores de chão". Nossos resultados também indicam que as restingas apresentam "espaços ecomorfológicos" disponíveis (nichos vagos) para ocupação por espécies adicionais de lagartos.

PALAVRAS-CHAVE. Estrutura de comunidades; Floresta Atlântica; morfometria; nicho vago.

Morphology of animal species can be used to describe and compare communities, based on the premise that adaptations of organisms reflect their ecological relationships. If environment imposes constraints on the adaptation of organisms and these are expressed simultaneously in their morphology and ecology, then morphological comparisions of sets of coexisting species should also have predictable ecological properties (KARR \& JAMES 1975). In the ecomorphological aproach, the "morphological space" is mapped closely into ecological space (Ricklefs \& Travis 1980). There are some classical examples of studies of vertebrate communities demonstrating this assumption: Hespenheide (1971, 1973), Cody \& Mooney (1978), and Ricklefs \& Travis (1980), working with birds; Findley $(1973,1976)$ with bats, and Ricklefs et al. (1981) and Irschick et al. (1997), studying lizards.

Correlations among habitat structure, ecology and morphology of coexisting lizard species are well documented in Moermond (1979a, b, 1986), Pounds (1988), and Irschick \& Losos (1999). Relative leg lengths are strongly correlated with habitat use and head lengths correlated with prey size (PIANKA 1969,

Revista Brasileira de Zoologia 24 (3): 786-792, setembro 2007 
Pianka \& Parker 1972, Pianka \& Pianka 1976). However, despite suggestions that space usage is a stronger factor (more than food usage) in determining the structure of lizard communities (Ricklefs et al. 1981, ARAújo 1991), this question remains unsatisfactorily tested. Most of the studies on lizard community-ecology in Brazil have been conducted in open habitats of the southeasthern coast (restinga vegetation, ARAújo 1984, 1991), Cerrado (Vitt 1991, Brandão \& Araújo 1998, 2001, Colli et al. 2002) and Caatinga dry woods (VAnzolini 1976, VitT 1995). Most of these works dealt with general aspects of space, food and time usage by lizards, only a few were dedicated to the study of ecomorphology (ARAújo 1991, TeiXeIra-Filho et al. 2001, Ribas et al. 2004, Pinto \& Ávila-Pires 2004).

Coastal restingas are Brazilian habitats easily accessible for this sort of study because of the type of formation and the abundance and easiness of surveying lizards (ARAÚJo 1984, 1991). This open xeromorphic habitat covers the recent Quaternary sand-dunes of the coast (LACERDA et al. 1984) and is characterized by landscapes dominated by scrubs, cacti, bromeliads, and grass patches, with extended areas of exposed sand. Considering its recent history (Suguio \& Tessler 1984, Flexor et al. 1984, Muehe 1984, Roncarati \& Menezes 2005), we expected an invasion-structured pattern (RUMMEL \& RoughGARDEN 1983) to be present in the lizard communities of restingas: high morphological overlap to use some good resources and low species packing. In order to evaluate this hypothesis, we investigated the morphological attributes of the restinga lizard assemblage of Marambaia, and compare our results to another restinga area of Southeastern Brazil.

\section{MATERIAL AND METHODS}

The present work was conducted in Marambaia, located in Sepetiba Bay, Mangaratiba, Rio de Janeiro State (between $23^{\circ} 04^{\prime} 51^{\prime \prime} \mathrm{S}-44^{\circ} 00^{\prime} 39^{\prime \prime} \mathrm{W}$ and $\left.23^{\circ} 03^{\prime} 48^{\prime \prime} \mathrm{S}-43^{\circ} 33^{\prime} 96^{\prime \prime} \mathrm{W}\right)$. Marambaia is physically partitioned in two distinct geographical areas, the Marambaia paleo-island and the contiguous Restinga da Marambaia (Fig. 1). The restinga area is composed of a $40 \mathrm{~km}$ sand bar, deposited along the last 5100 years (Roncarati \& Menezes 2005). The paleo-island has its highest peak reaching $640 \mathrm{~m}$ and holds beaches with restinga vegetation, rocky shoreline, small mangrove patches and Atlantic Forest, with high habitat heterogeneity (CONDE et al. 2005, Menezes \& Araújo 2005).

Lizard sampling took place between July 2003 and July 2005. Lizards were observed along trails, collected and fixed with $10 \%$ formalin, to obtain morphometric data, following the protocol presented by ARAújo (1991). Nine measurements of the lizards collected were taken using a digital caliper $( \pm 0.05 \mathrm{~mm})$ : snout-vent length, arm length, hand length, leg length, foot length, head length, head width, head height and jaw length. For this study, only the lizards that occur in restingas were considered. 120 specimens collected are housed in the Coleção Herpetológica do Laboratório de Herpetologia da Universidade Fed- eral Rural do Rio de Janeiro (CH-UFRRJ), and a list of the vouchers is presented in appendix I.

Lizard measurements were log transformed and ordinated with Principal Components Analysis (PCA, using the covariance matrix, Pielou 1984), following Ricklefs et al. (1981). The identification of ecomorphological groups of lizard species were confirmed using Discriminant Analysis. In order to evaluate the morphological affinities of each lizard species, a Cluster Analysis (Ward's method) was performed using the mean of the scores of the first and second principal components for each species (centroid) genereted by PCA. All statistical analysis were performed using SYSTAT 11.0, except by the Cluster Analysis, executed using PAST.

\section{RESULTS AND DISCUSSION}

Of the 12 lizard species known to occur in Marambaia (CARVALHo et al. 2007), nine were encountered during our surveys in the restingas: Ameiva ameiva (Linnaeus, 1758) $(\mathrm{n}=6)$, Cnemidophorus littoralis Rocha, Araujo, Vrcibradic \& Costa, 2000 $(\mathrm{n}=5)$, Gymnodactylus darwinii (Gray, 1845) $(\mathrm{n}=7)$, Hemidactylus mabouia (Moreau de Jonnès, 1818) $(\mathrm{n}=6)$, Liolaemus lutzae Mertens, 1938 ( $\mathrm{n}=6)$, Mabuya agilis (Raddi, 1823) ( $\mathrm{n}=4)$, Mabuya macrorhyncha Hoge, 1947 ( $\mathrm{n}=4$ ), Tupinambis merianae (Duméril \& Bibron, 1839) $(\mathrm{n}=1)$, and Tropidurus torquatus (Wied, 1820) (n $=81$ ). Table I presents the measurements of the lizards colected. The most common species was T. torquatus, easily observed in the restingas, as in other habitats of Marambaia. Mabuya agilis was recorded in the restingas and forest habitats, while $M$. macrorhyncha was only found in the restingas. Cnemidophorus littoralis was encountered only in the restinga scrubs, and L. lutzae only in the fields of the dunes facing the open sea. Surprisingly, A. ameiva was observed in the forest gaps and in the restinga boundaries, but not in the restinga scrubs, or in the restinga beach dunes of Marambaia. This teiid is commonly encountered in the scrub habitat of others restingas (ARAúJo 1991, Freire 1996, TeiXeIRA 2001, Rосна et al. 2004). In addition to being found in the restingas, $G$. darwinii was recorded in the forests also, as was the other gekkonid in our study, H. mabouia.

The hypothesis of an invasion-structured pattern (RUMMEL \& Roughgarden 1983), with high morphological overlap among species, and low levels of species packing, was confirmed. The morphometric analysis distinguished two lizard groups (Discriminant Analysis, Wilks' lambda $=0.139 ; \mathrm{df}=3,116 ; \mathrm{p}=0.000 ;$ PCA plots; Figs 2 and 3, Tab. II). The first group included T. torquatus, A. ameiva, L. lutzae, C. littoralis, and T. merianae. The second group included H. mabouia, G. darwinii, M. agilis, and M. macrorhyncha. To classify these ecomorphological groups of lizards, we modified the nomenclature proposed by AraÚjo (1991). The group formed by robust lizards with long extremities (T. torquatus, $A$. ameiva, L. lutzae, C. littoralis, and T. merianae) was named "groundrunners", and the other group, composed of small and slender lizard species, with short limbs, was denominated "hiders" ( $H$. mabouia, G. darwinii, M. agilis, and M. macrorhyncha). 


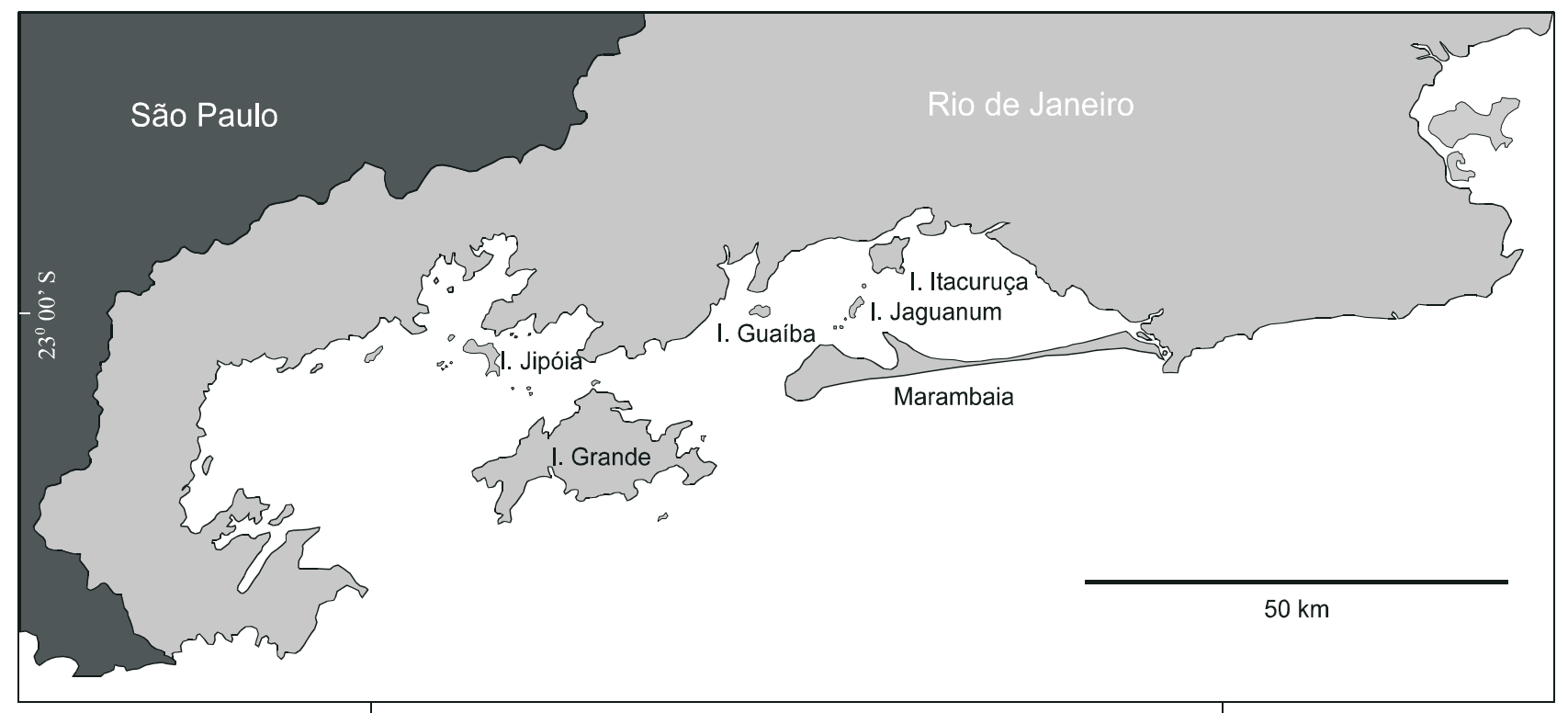

$44^{0} 30^{\prime} \mathrm{W}$

$44^{0} 30^{\prime} \mathrm{W}$

Figure 1. Map of the southern portion of the State of Rio de Janeiro, with the location of Marambaia and other nearby islands and coastal areas.
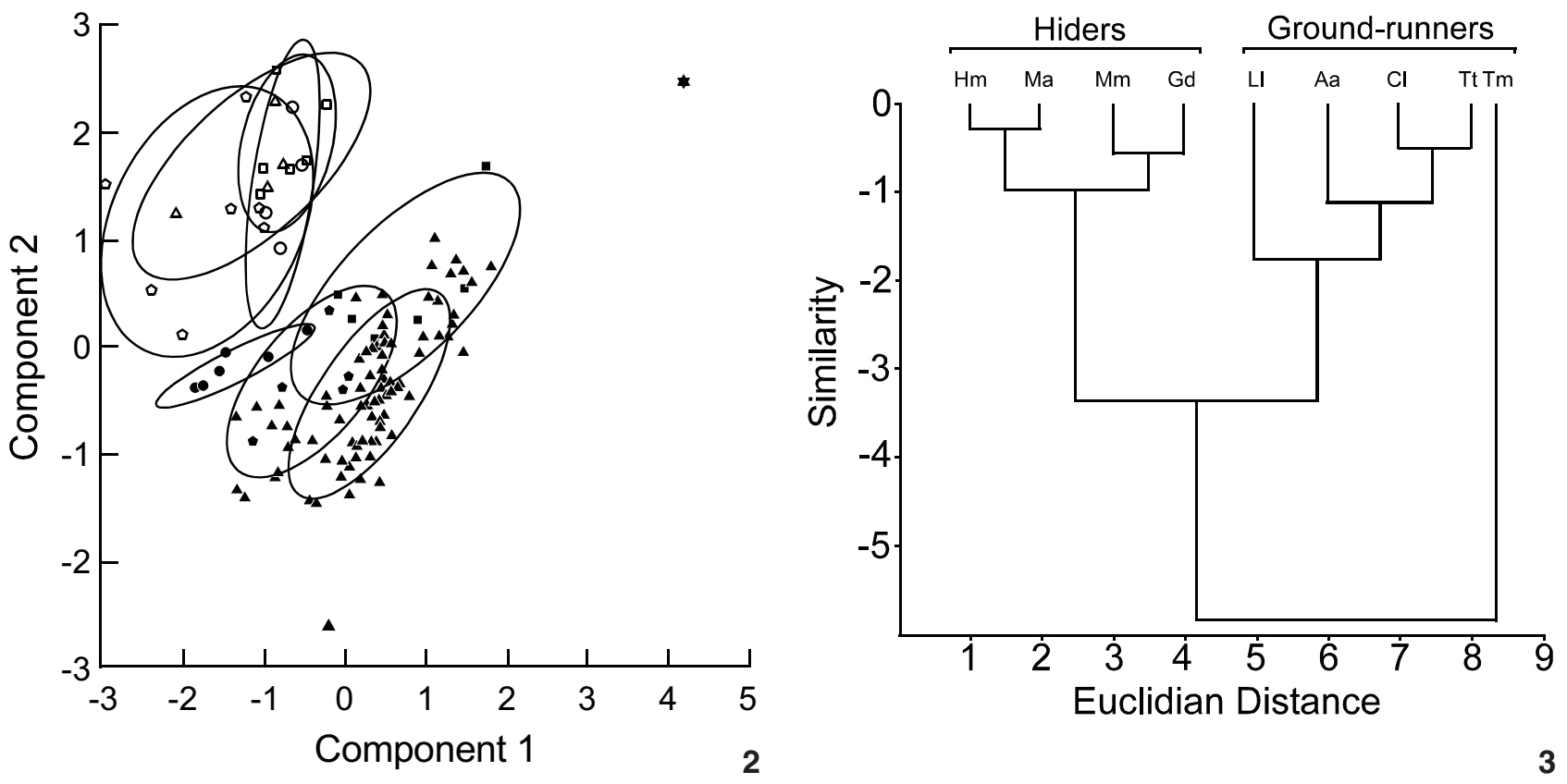

Figures 2-3. (2) Scaterplot of the first and second principal components generated by the morphometric analysis of the lizards of

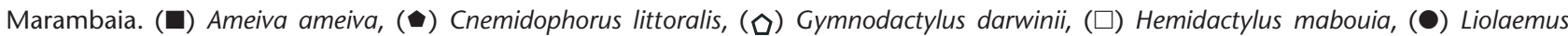
lutzae, $(\bigcirc)$ Mabuya agilis, $(\triangle)$ M. macrorhyncha, $(\star)$ Tupinambis merianae, $(\mathbf{\Delta})$ Tropidurus torquatus. (3) Euclidian distances and morphometric similarity levels for the lizard species of Marambaia. Cophenetic correlation coefficient $=0.92$ (clustering by Ward's method). (Aa) Ameiva ameiva, (Cl) Cnemidophorus littoralis, (Gd) Gymnodactylus darwinii, (Hm) Hemidactylus mabouia, (LI) Liolaemus lutzae, (Ma) Mabuya agilis, (Mm) M. macrorhyncha, (Tm) Tupinambis merianae, (Tt) Tropidurus torquatus.

Revista Brasileira de Zoologia 24 (3): 786-792, setembro 2007 


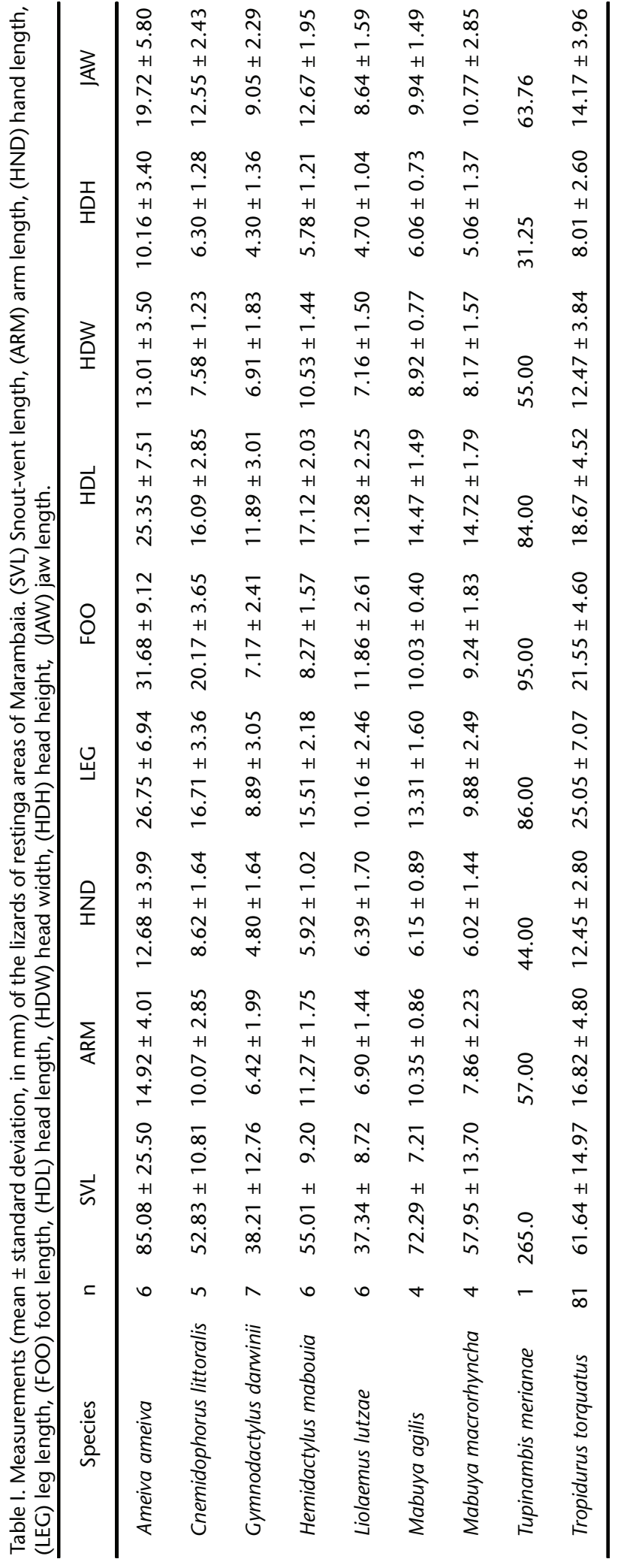

The morphometric assemblage resulting from the present investigation is congruent with that reported by ARAújo (1991) for the lizard community of restinga de Maricá (also in the State of Rio de Janeiro). The morphometric relationships observed for both lizard communities suggest that phylogeny partially explains ecological relationships: the group of hider lizards includes only scleroglossian species, while ground-runners included both scleroglossan and iguanian lizard species (i.e., both major clades of Lacertilia; VITT et al. 2003).

The sum of the principal component values (Tab. II) suggest that the variables associated with space usage (limb measurements) are as important in explaining the total variance as variables associated with diet (i.e., head measurements). However, the highest score value pertains to a variable relating to the use of space (foot length), indicating that habitat structure is the most important factor clustering the two groups of lizards identified in our study. The availability and distribution of bromeliads, as well as the distribution of other refugia, are important to the "hiders", whereas open areas between scrubs are important to "ground-runners". Similar results were found by RickLefs et al. (1981), studying lizard communities of deserts in three continents (North America, Africa and Australia), who applied the same protocol to the lizards collected by PIANKA $(1973,1975)$.

Considering that the ecomorphological groups of lizards of Marambaia present distinct strategies for escaping predation - run to the scrubs ("ground-runners") and hide inside bromeliads and other refugia ("hiders") - our results also suggest that predation may be another important ecological factor structuring lizard communities of restingas. However, a test of this hypothesis requires experimental analyses that are beyond the scope of the present study.

Gymnophthalmids and polychrotids, extensively sympatric in different localities of the Cerrado (VITT 1991, BRANDão \& ARAújo 1998, 2001, Colli et al. 2002) and Caatinga (VITt 1995, Borges-Nojosa \& CARAMASChI 2003), are absent in the southeastern Brazilian restingas. The absence of small gymnophthalmids in the litter cannot be explained by the absence of litter, which is present in restingas. The same reasoning applies to the absence of arboreal polychrotids and leiosaurids, because trees are common in restingas also. The explanation for these vacant ecomorphometrical spaces seems to relate to the nonexistence of lizard species in the Atlantic-Forest stock capable of colonizing restinga scrubs, which are drier and hotter than the humid forest more to the interior of the continent.

FreIrE (1996) pointed out the influence of the Caatinga lizard fauna on the composition of two restinga lizard communities of northeastern Brazil, inhabited by a common gymnophthalmid species of open areas, Micrablepharus maximiliani (Reinhardt \& Luetken, 1862). The Atlantic Forest arboreal lizards, Anolis fuscoauratus D'Orbigny, 1837, A. ortonii Cope, 1868, and Enyalius bibronii Boulenger, 1885, occur in the northeastern restingas, but associated with dry forests, not with the scrub habitats. In addition, even in Marambaia, species of Gymnoph- 
Table II. Eigenvalues (EVL), eigenvectors (EVT) and explained variance (\%) generated by the Pricipal Component Analysis (covariance matrix), using the log transformed measurements of the lizards of Marambaia.

\begin{tabular}{|c|c|c|c|c|c|c|}
\hline & \multicolumn{2}{|c|}{ Component 1} & \multicolumn{2}{|c|}{ Component 2} & \multicolumn{2}{|c|}{ Component 3} \\
\hline & EVL & EVT & EVL & EVT & EVL & EVT \\
\hline Snout-vent length & 0.130 & 0.286 & 0.047 & 0.415 & 0.001 & 0.014 \\
\hline Arm length & 0.167 & 0.366 & -0.021 & -0.186 & -0.048 & -0.603 \\
\hline Hand length & 0.160 & 0.352 & -0.038 & -0.332 & -0.009 & 0.109 \\
\hline Leg length & 0.186 & 0.408 & -0.030 & -0.265 & -0.027 & -0.333 \\
\hline Foot length & 0.179 & 0.394 & -0.052 & -0.459 & 0.049 & 0.619 \\
\hline Head length & 0.123 & 0.270 & 0.037 & 0.328 & 0.010 & 0.119 \\
\hline Head width & 0.137 & 0.300 & 0.029 & 0.250 & -0.017 & -0.210 \\
\hline Head height & 0.141 & 0.310 & 0.027 & 0.240 & 0.009 & 0.109 \\
\hline Jaw length & 0.128 & 0.281 & 0.048 & 0.417 & 0.019 & 0.244 \\
\hline Explained Variance & \multicolumn{2}{|c|}{87.931} & \multicolumn{2}{|c|}{5.542} & \multicolumn{2}{|c|}{2.706} \\
\hline
\end{tabular}

thalmidae, Leiosauridae and Polychrotidae use the forested habitats next to the restinga scrubs, but not the scrubs themselves (CARvalHo et al. 2007), what reinforce the hypothesis of non-saturated lizard communities in southeastern coastal areas be determinated by physiological constraints of the stock of species present in the Atlantic Forest.

The existence of community saturation in nature is contested by evidence that community structuring mechanisms may be related to extrinsic biogeographical events, rather than intrinsic local processes (Cornell \& LAWTON 1992). Some authors present evidence for random structure of the natural communities (Ricklefs \& Travis 1980, Ricklefs et al. 1981, Gilpin \& Diamond 1984, SimberLofF 1984). Others contested this with evidence that evolution has indeed produced nonrandom assemblages of interacting species (Gatz 1979, Schoener 1984). Nevertheless, restinga vegetation is extremely dynamic - in a few decades, the grassfields of the beaches can be replaced by scrub patches, after which the shrubs can grow and fuse to form a dry forest, leading to a humid forest, connected to the mainland (LACERDA et al. 1984) - and the spatial heterogeneity due to the ecological sucession permits space niche partitioning among the lizard species (Araújo 1984, 1991). However, the existence of vacant niches (marked by the absence of semifossorial and arboreal lizards) is evident in the southeastern Brazilian restingas; the existence of empty ecomorphological spaces in the analysis reinforces this idea.

\section{ACKNOWLEDGMENTS}

We are thankful to the Brazilian Navy, especially to the commanding officer of CADIM (Centro de Adestramento da Ilha da Marambaia) for the logistic support during field work; to the students and collegues of the Laboratory of Herpetology, Universidade Federal Rural do Rio de Janeiro, in special Roberta R. da Silva-Leite, for their help in the field and laboratory; to Hélio R. da Silva (UFRRJ) and Joseph Mendelson (Atlanta Zoo) for the review of the manuscript. The MCT-CNPq provided support for this research through the Scientific Initiation Fellowship given to ALGC and the grant process CNPq 471081/04-3.

\section{REFERENCES}

AraúJo, A.F.B. 1984. Padrões de Divisão de Recursos em Uma Comunidade de Lagartos de Restinga, p. 327-342. In: L.D. Lacerda; D.S.D. Araújo; R. Cerqueira \& B. Turce (Eds). Restingas: origem, estrutura, processos. Niterói, CEUFF, Universidade Federal Fluminense, 477p.

Araújo, A.F.B. 1991. Structure of a White sand-dune lizard community of coastal Brazil. Revista Brasileira de Biologia 54 (4): 857-865.

Borges-Nojosa, D.M. \& U. Caramaschi. 2003. Composição e análise comparativa da diversidade das afinidades biogeográficas dos lagartos e anfisbenídeos (Squamata) dos brejos nordestinos, p. 463-512. In: I.R. Leal; M. Tabarelli \& J.M.C. Silva (Eds). Ecologia e conservação da Caatinga. Recife, Editora Universitária UFPE, 822p.

Brandão, R.A. \& A.F.B. Araújo. 1998. Herpetofauna de Águas Emendadas, p. 9-21. In: J.S. Marinho-Filho; F.G. Rodrigues \& M. Guimarães (Eds). Vertebrados da Estação Ecológica de Águas Emendadas. Brasília, SEMATEC, 92p.

Brandão, R.A. \& A.F.B. Araújo. 2001. A Herpetofauna associada ás matas de galeria do Distrito Federal, p. 9-21. In: J.F. RibeIRO; C.E.L. FonseCa \& J.C. SousA-Silva (Eds). Cerrado - caracterização e recuperação de matas de galeria. Planaltina, Embrapa Cerrados, 889p.

Carvalho, A.L.G.; A.F.B. Araújo \& H.R. Silva. 2007. Lagartos da Marambaia, um Remanescente Insular de Restinga e Floresta Atlântica no Estado do Rio de Janeiro. Biota Neotropica 7 (2): 1-5.

Cody, M.L. \& H.A. Mooney. 1978. Convergence versus Nonconvergence in Mediterranean-climate Ecosystem. Annual Review of Ecology and Systematics 9: 265-321. 
Colli, G.R.; R.P. Bastos \& A.F.B. Araújo. 2002. The Character and Dynamics of the Cerrado Herpetofauna, p. 223-241. In: P.S. Oliveira \& R.J. Marquis (Eds). The Cerrados of Brazil: ecology and natural history of a Neotropical Savanna. New York, Columbia University Press, vol. 1, 398p.

Conde, M.M.S.; H.R.P. Lima \& A.L. Peixoto. 2005. Aspectos Florísticos e Vegetacionais da Marambaia, Rio de Janeiro, Brasil, p. 133-168. In: L.F.T. Menezes; A.L. Peixoto \& D.S.D. Araújo (Eds). História natural da Marambaia. Seropédica, Editora da Universidade Federal Rural do Rio de Janeiro, 260p.

Cornell, H.V. \& J.H. LaWton. 1992. Species Interactions, local and regional processes, and limits to the richness of ecological communities: a theoretical perspective. Journal of Animal Ecology 61: 1-12.

FIndLey, J.S. 1973. Phenetic packing as a measure of faunal diversity. The American Naturalist 107 (956): 580-584.

Findley, J.S. 1976. The structure of bat communities. The American Naturalist 110: 129-139.

Flexor, J.M.; L. Martin; K. Suguio \& J.M.L. Domingues. 1984. Gênese dos cordões litorâneos da parte central da costa brasileira, p. 35-46. In: L.D. Lacerda; D.S.D. Araújo; R. Cerqueira $\&$ B. TURCQ (Eds). Restingas: origem, estrutura, processos. Niterói, CEUFF, Universidade Federal Fluminense, 477p.

Freire, E.M.X. 1996. Estudo ecológico e zoogeográfico sobre a fauna de lagartos (Sauria) das dunas de Natal, Rio Grande do Norte e da Restinga de Ponta de Campina, Cabedelo, Paraíba, Brasil. Revista Brasileira de Zoologia 13 (4): 903-921.

Gatz, A.J. 1979. Community Organization in Fishes as Indicated by Morphological Features. Ecology 60: 711-718.

Gilpin M.E \& J.M. Diamond. 1984. Are Species co-occurrences on islands non-random, and are null hypotheses useful in community ecology?, p. 297-315. In: D.R. STrong; D. Simberloff; L.G. Abele \& A.B. Thistle (Eds). Ecological communities: conceptual issues and the evidence. Princeton, Princeton University Press, XIII+613p.

Hespenheide, H.A. 1971. Food Preference and the extent of overlap in some insectivorous birds with special reference to the Tyrannidae. Ibis 113: 59-72.

Hespenheide, H.A. 1973. Ecological inferences from morphological data. Annual Review of Ecology and Systematics 4: 213230.

IRschick, D.J. \& J.B. Losos. 1999. IRschick, D.J. \& J.B. Losos. 1999. Do lizards avoid habitats in which performance is submaximal? The relationship between sprinting capabilities and structural habitat use in Caribbean Anoles. The American Naturalist 154 (3): 293-305.

IRSCHICK, D.J.; L.J. VITT; P.A. ZANI \& J.B. Losos. 1997. A Comparation of evolutionary radiations in mainland and Caribbean Anolis lizards. Ecology 78 (7): 2191-2203.

KARR, J.R. \& F.C. JAMEs. 1975. Ecomorphological Configuration and Convergent Evolution in Species and Communities, p. 258291 In: M.L. Cody \& J.M. DiAMOND (Eds). Ecology and evolution of communities. Massachusetts, Belknap Press, XII+545p.
Lacerda, L.D.; D.S.D. Araújo; R. Cerqueira \& B. Turce. 1984. Restingas: origem, estruturas, processos. Niterói, CEUFF, Universidade Federal Fluminense, 477p.

Menezes, L.F.T. \& D.S.D. AraúJo. 2005. Formações vegetais da Restinga da Marambaia, p. 67-120 In: L.F.T. MEnezes; A.L. Peixoto \& D.S.D. Araujo (Eds). História natural da Marambaia. Seropédica, Editora da Universidade Federal Rural do Rio de Janeiro, 260p.

Moermond, T.C. 1979a. Habitat Constraints on the behavior, morphology, and community structure of Anolis lizards. Ecology 60: 152-164.

Motrmond, T.C. $1979 \mathrm{~b}$. The influence of habitat structure on Anolis foraging behaviour. Behaviour 70: 141-167.

Moermond, T.C. 1986. A mechanistic approach to the structure of animal communities: Anolis lizards and birds. American Zoologist 26: 23-37.

MueHe, D. 1984. Evidência de recuos dos cordões litorâneos em direção ao continente no litoral do Rio de Janeiro, p. 75-80. In: L.D. Lacerda; D.S.D. Araújo; R. Cerqueira \& B. Turce (Eds). Restingas: origem, estrutura e processos. Niterói, CEUFF, Universidade Federal Fluminense, 477p.

PIANKA, E.R. 1969. Habitat specificity, speciation and species density in Australian desert lizards. Ecology 50: 498-502.

PiankA, E.R. 1973. The structure of lizard communities. Annual Review of Ecology and Systematics 4: 53-74.

PIANKA, E.R. 1975. Niche relations of desert lizards, p. 292-314. In: M.L. Cody \& J.D. Diamond (Eds). Ecology and evolution of communities. Cambridge, Belknap, XII+545p.

Pianka, E.R. \& H.D. Pianka. 1976. Comparative ecology of twelve species of nocturnal lizards (Gekkonidae) in the western Australian deserts. Copeia 1976: 125-142.

Pianka, E.R. \& W.S. Parker. 1972. Ecology of the iguanid Callisaurus draconoides. Copeia 1972: 493-508.

Pielou, E.C. 1984. The interpretation of ecological data. New York, John Wiley and Sons, 263p.

Pinto, G.S. \& T.C.S. Ávila Pires. 2004. Crescimento Alométrico, morfologia e uso de habitat em cinco espécies de Mabuya Fitzinger (Reptilia, Scincidae). Revista Brasileira de Zoologia 21 (2): 161-168.

Pounds, J.A. 1988. Ecomorphology, locomotion, and microhabitat structure: patterns in a tropical mainland Anolis community. Ecological Monographs 58: 299-320.

Ribas, S.C.; A.L.R. Veloso; P. Teixeira-Filho; O. Rocha-Barbosa; H. Evangelista \& E.A. Santos. 2004. Structure of claws and toes of two tropidurid lizard species of restinga from southeastern Brazil: adaptations to the vertical use of the habitat. Revista Chilena de Historia Natural 77 (4): 599-606.

Ricklefs, R.E. \& J. Travis. 1980. A Morphological approach to the study of avian community organization. Auk 97: 321-338.

Ricklefs, R.E.; D. Cochran \& E.R. Pianka. 1981. A morphological analysis of the structure of communities of lizards in desert habitats. Ecology 62: 1474-1483.

Rocha, C.F.D.; M. Van-Sluys; D. Vrcibradic; F.H. Hatano; C.A. 
Galdino; M. Cunha-Barros \& M.C. Kieffer. 2004. A comunidade de répteis da Restinga de Jurubatiba, p. 179-198. In: C.F.D. Rocha; F.A. Esteves \& F.R. Scarno (Eds). Pesquisas ecológicas de longa duração na Restinga de Jurubatiba: ecologia, história natural e conservação. São Carlos, RiMa Editora, vol.1, 376p.

Roncarati, H. \& L.F.T. Menezes. 2005. Marambaia, Rio de Janeiro: origem e evolução, p. 15-38. In: L.F.T. Menezes; A.L. Peixoto \& D.S.D. ARAújo (Eds). História natural da Marambaia. Seropédica, Editora da Universidade Federal Rural do Rio de Janeiro, 260p.

Rummel, J.D. \& J. Roughgarden. 1983. Some Differences between invasion-structured and coevolution-structured competitive communities: a preliminary theoretical analysis. Oikos 41: 477-486.

Schoener, T.W. 1984. Size Differences among sympatric, birdeating hawks, p. 254-281. In: D.R. Strong; D. Simberloff; L.G. Abele \& A.B. Thistle (Eds). Ecological communities: concepts issues and the evidence. Princeton, Princeton Universtity Press, 620p.

Simberloff, D. 1984. Properties of coexisting bird species in two archipelagoes, p. 234-253. In: Ecological communities: conceptual issues and evidence. Princeton, Princeton
University Press, 620p.

Suguio, K. \& M.G. Tessler. 1984. Planícies de cordões arenosos quaternários do Brasil: origem e nomenclatura, p. 15-26. In: L.D. Lacerda; D.S.D. Araújo; R. Cerqueira \& B. Turce (Eds). Restingas: origem, estrutura, processos. Niterói, CEUFF, Universidade Federal Fluminense, 477p.

TeiXeIrA, R.L. 2001. Comunidade de lagartos da Restinga de Guriri, São Mateus - ES, sudeste do Brasil. Atlântica 23: 77-94.

Teixeira-Filho, P.; O. Rocha-Barbosa; V. Paes; S.C. Ribas \& J.R. Almeida. 2001. Relaciones ecomorfológicas en seis especies de lagartos de la Restinga de la Barra de Maricá, Río de Janeiro, Brasil. Revista Chilena de Anatomia 19(1): 45-50.

VANZOLINI, P.E. 1976. On the lizards of cerrado-caatinga contact: evolutionary and zoogeographical implications (Sauria). Papéis Avulsos de Zoologia 29: 111-119.

VITT, L.J. 1991. An introduction to the ecology of cerrado lizards. Journal of Herpetology 25 (1): 79-90.

VITT, L.J. 1995. The ecology of tropical lizards in the caatinga of northeast Brazil. Occasional Papers of the Oklahoma Museum of Natural History 1:1-29.

VitT, L.J.; E.R. Pianka; W.E. Cooper-Jr \& K. Schwenk. 2003. History and the global ecology of squamate reptiles. The American Naturalist 162 (1): 44-60.

Appendix. List of the lizards collected in Marambaia, Mangaratiba, Rio de Janeiro, Brazil. The specimens are housed in the Coleção Herpetológica, Laboratório de Herpetologia, Universidade Federal Rural do Rio de Janeiro (RU).

\begin{tabular}{|c|c|}
\hline Species & Collection number \\
\hline Ameiva ameiva & RU 715, RU 716, RU 717, RU 718, RU 719, RU 720 \\
\hline Cnemidophorus littoralis & RU 721, RU 722, RU 723, RU 724, RU 725 \\
\hline Gymnodactylus darwinii & RU 734, RU 742, RU 746, RU 893, RU 902, RU 944, RU 983 \\
\hline Hemidactylus mabouia & RU 735, RU 726, RU 727, RU 899, RU 900 \\
\hline Liolaemus lutzae & RU 736, RU 737, RU 738, RU 739, RU 740, RU 741 \\
\hline Mabuya agilis & RU 728, RU 729, RU 730, RU 731 \\
\hline Mabuya macrorhyncha & RU 731, RU 733, RU 744, RU 904 \\
\hline Tropidurus torquatus & 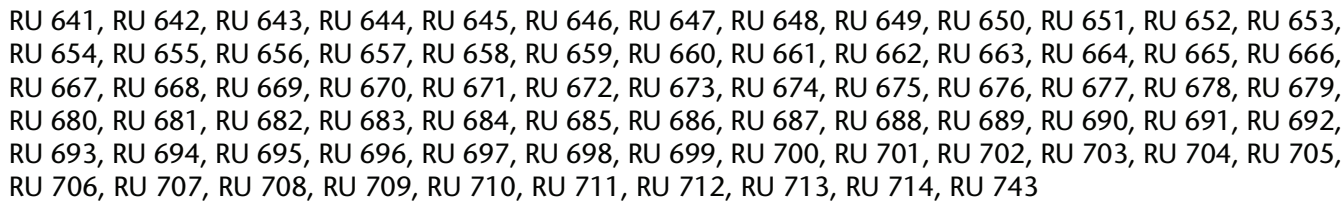 \\
\hline Tupinambis merianae & RU 747 \\
\hline
\end{tabular}

Received in 05.VI.2007; accepted in 23.VIII.2007. 